\title{
The Regulation of CIN-like TCP Transcription Factors
}

\author{
Jingqiu Lan ${ }^{1}$ and Genji Qin ${ }^{1,2, *}$ \\ 1 State Key Laboratory of Protein and Plant Gene Research, School of Life Sciences, Peking University, \\ Beijing 100871, China; lanjq@pku.edu.cn \\ 2 School of Advanced Agricultural Sciences, Peking University, Beijing 100871, China \\ * Correspondence: qingenji@pku.edu.cn
}

Received: 30 May 2020; Accepted: 20 June 2020; Published: 24 June 2020

\begin{abstract}
TEOSINTE BRANCHED1/CYCLOIDEA/PROLIFERATING CELL FACTOR 1 and 2 (TCP) family proteins are the plant-specific transcription factors extensively participating in diverse developmental processes by integrating external cues with internal signals. The roles of CINCINNATA (CIN)-like TCPs are conserved in control of the morphology and size of leaves, petal development, trichome formation and plant flowering. The tight regulation of CIN-like TCP activity at transcriptional and post-transcriptional levels are central for plant developmental plasticity in response to the ever-changing environmental conditions. In this review, we summarize recent progresses with regard to the function and regulation of CIN-like TCPs. CIN-like TCPs are regulated by abiotic and biotic cues including light, temperature and pathogens. They are also finely controlled by microRNA319 (miRNA319), chromatin remodeling complexes and auxin homeostasis. The protein degradation plays critical roles in tightly controlling the activity of CIN-like TCPs as well.
\end{abstract}

Keywords: CIN-like TCP transcription factors; regulation; light; high temperature; microRNA319; BRAHMA; TIE1 transcriptional repressors; TEAR1 E3 ligases

\section{Introduction}

Developmental plasticity is central for sessile plants in adaptation to the environmental conditions [1]. The molecular bases for plant developmental plasticity or the mechanisms by which plants translate the environmental cues into the internal signals to direct the optimal growth and development in different plant growing conditions are important for plant survival and are useful for crop improvement by molecular breeding. Since the discovery of the founding members of TEOSINTE BRANCHED1/CYCLOIDEA/PROLIFERATING CELL FACTOR 1 and 2 (TCP) protein family in plants more than twenty years ago [2-4], TCP proteins have emerged as a central hub for integrating the internal and external cues to control plant developmental plasticity.

TCP is an acronym of the name of founding genes isolated from three species, i.e., TEOSINTE BRANCHED1 (TB1) from maize (Zea mays) [2,5], CYCLOIDEA (CYC) from snapdragon (Antirrhinum majus) [3], and PROLIFERATING CELL FACTOR 1 and 2 (PCF1 and PCF2) from rice (Oryza sativa) [4]. TB1 is a famous maize domestication gene. TB1 represses the outgrowth of axillary branches and promotes the formation of female inflorescences in domesticated maize, while in teosinte-which is the wild ancestor of maize - the twice lower expression of TB1 leads to a decrease of apical dominance and an increase of shoot branches [5]. The CYC gene was isolated from snapdragon. CYC is specifically expressed in the dorsal primordia and controls the flower zygomorphic trait. Disruption of both CYC and its close homolog DICHOTOMA (DICH) in snapdragon results in radially symmetric flowers [6]. Both TB1 and CYC play pivotal roles in shaping plant key morphologies. The rice PCF proteins were found to directly bind to the promoter region of PROLIFERATING CELL NUCLEAR ANTIGEN (PCNA) gene which encodes a protein acting as a DNA polymerase sliding clamp implicated in DNA replication 
and cell cycle regulation [4]. Further analysis of the protein sequences of TB1, CYC and PCF proteins found that they all contain a conserved region predicted to form a non-canonical basic helix-loop-helix (bHLH) structure named as the TCP domain [7]. Since PCF1 and PCF2 had DNA-binding activity, TCP proteins were deduced to act as transcription factors and the TCP domain was proposed to be responsible for DNA binding and protein-protein interaction $[4,7,8]$.

According to the sequence differences in the TCP domain, TCPs are classified into class I and class II subfamilies [7] (Figure 1). The TCP domain of class II TCPs contains additional four-amino acid residues in the conserved basic region [7]. The class II TCPs are further divided into CINCINNATA (CIN)-like TCPs and CYC/TB1-like TCPs based on the additional sequence differences in the TCP domain [9]. The CYC/TB1 TCP subgroup also carries a conserved glutamic acid-cysteine-glutamic acid (ECE) motif outside the TCP domain [10]. The CIN gene was isolated from snapdragon by analyzing the cin mutant which produces abnormal leaves and petals with undulated edges $[11,12]$ and is the founding member of the CIN-like TCP subgroup (Figure 1). CIN controls leaf flatness by tightly regulating cell proliferation and differentiation in the different areas of leaf blades [11]. In the model plant Arabidopsis, the CIN-like TCPs include eight members which are further grouped into two clades based on the existence of microRNA (miRNA) binding site outside the sequence encoding TCP domain. TCP2, TCP3, TCP4, TCP10, and TCP24 have the miRNA binding sites and post-transcriptionally regulated by miR319 [13], while TCP5, TCP13 and TCP17 form a small clade named as TCP5-like CIN-TCPs that were proved to be important for plant thermomorphogenesis (Figure 2) [14].

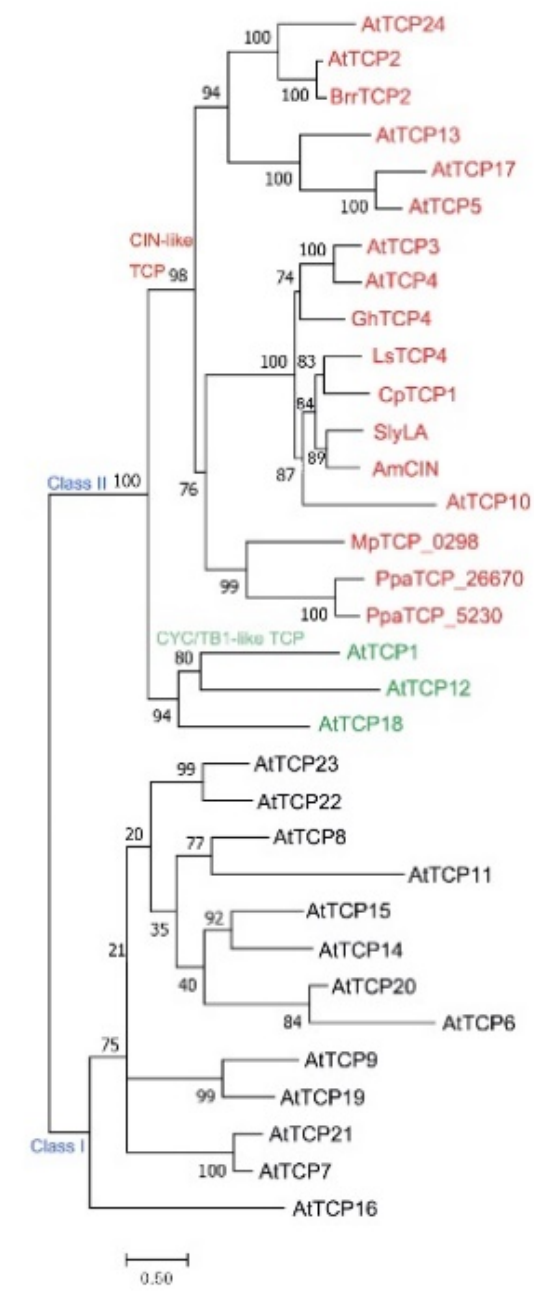

Figure 1. The phylogeny of TCP transcription factors, including all the TCP proteins in Arabidopsis thaliana 
and the CIN-like TCPs of other species mentioned in this review. Multiple alignments of the full-length TCP proteins were conducted using MAFFT Version 7 [15] with L-INS-i iterative refinement methods. The phylogenetic tree was constructed with the Maximum Likelihood (ML) method using the IQ-tree2 software [16] with the VT+F+R4 model with 1000 bootstrap replications. The subfamilies and subclasses (Class I, Class II, CIN-like TCP and CYC-like TCPs) are indicated above the divergent branches. The proteins in red words are the CIN-like TCPs which are mainly discussed in this review. The prefixes of TCP proteins are indicated the species. At: Arabidopsis thaliana; Brr: Brassica rapa; Gh: Gossypium hirsutum; Ls: Lactuca sativa; Cp: Cyclamen persicum; Sly: Solanum lycopersium; Am: Antirrhinum majus; Mp: Marchantia polymorpha; Ppa: Physcomitrella patens. The bootstrap support is indicated above the branches. The scale bar denotes the branch length.

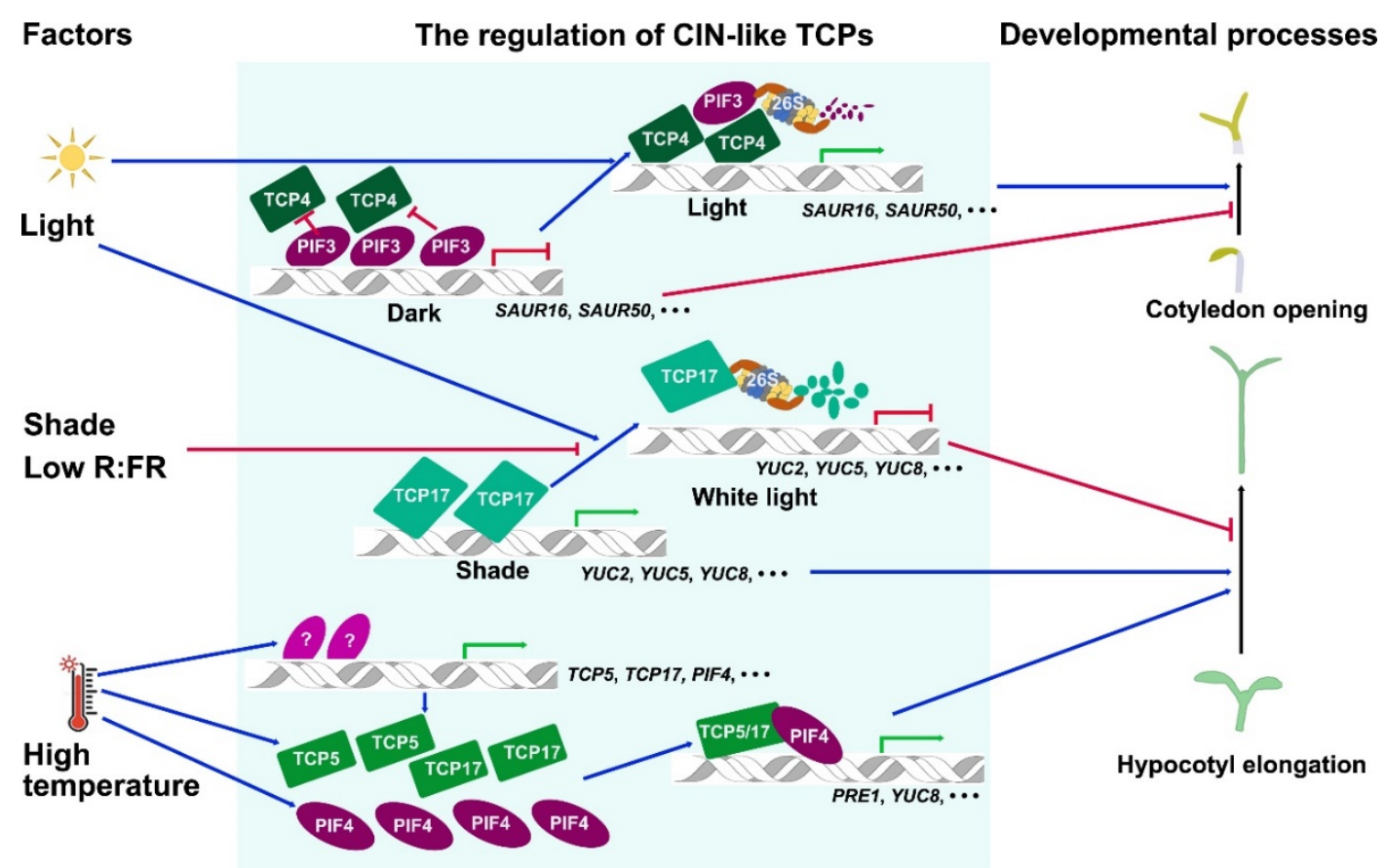

Figure 2. An overview of the regulation mechanisms of CIN-like TCP transcription factors by light and temperature during cotyledon opening and hypocotyl elongation processes. The external stimuli including light and high temperature are summarized at the left column. The schematic diagram includes the regulation mechanisms of CIN-like TCPs at the transcriptional and the protein levels. The arrows directly pointing on the double helix symbols indicate transcriptional regulations. The arrows pointing to the proteins indicate the regulations of protein stabilities. The proteins related with the "26S" symbols indicate protein degradation through the ubiquitin-26S proteasome pathway. The blue arrows represent the positive regulation, and the red arrows with dash-headed ends indicate the negative regulation. The green arrows and red dash-headed ends at the double-helix icons indicates the activation and repression of gene expression, respectively. All the unknown factors are indicated with question marks. R:FR, red light: far red light ratio; PIFs, PHYTOCHROME-INTERACTION FACTORs; SAURs, SMALL AUXIN UPREGULATED RNAs; YUCs, YUCCAs.

TCP transcription factors constitute a plant-specific protein family which is conserved in plant kingdom. TCP homologs are identified from diverse plant species [7]. It is proved that TCP proteins are existed in the early land plants during evolutionary history [17-20]. However, it is still in dispute whether they are present in pluricellular green algae $[17,20]$. The TCP protein family is significantly expanded in angiosperm species by gene or whole-genome duplication independently in basal angiosperm, magnoliids, basal eudicot, monocot, and many major groups within eudicot [10,17,20-25]. It is hard to distinguish whether class I or class II subfamily is the first to appear in plant kingdom, because the genome of liverwort Marchantia polymorpha contains the members belonging to both of the 
two families $[19,26]$. As for class II TCPs, the CIN-like TCP subgroup is predicted to be more ancestral than the CYC/TB1-like TCPs, since the class II TCPs all belong to CIN-like TCP subgroup in the non-vascular plants $[18,19,26,27]$. The CYC/TB1-like TCP group is proposed to originate in angiosperm species and to evolve independently in basal eudicot groups and monocot species [23,24,28-31].

TCP family transcription factors governs various key developmental processes during the life cycle of plants. TCPs regulate seed germination, leaf development, outgrowth of shoot branches, flowering, flower development, silique and ovule development, photomorphogenesis, thermomorphogenesis, circadian rhythms, defense responses and senescence [11,32-53]. The tight regulation of TCPs is very important for plant development and survival. Plants evolve many ways to tightly regulate TCP activity. The aim of this review is to give a comprehensive overview on current knowledge relevant to the roles of CIN-like TCPs in different species and the fine regulation of CIN-like TCP by external stimuli, miRNA and other proteins. To understand the detailed functions of TCPs in plants, the downstream targets regulated by TCPs, the regulation of CYC/TB1-like TCPs, please refer to the excellent recent reviews $[39,54,55]$.

\section{The Functions of CIN-Like TCP Transcription Factors in Different Species}

One of the most prominent roles of CIN-like TCP transcription factors is that they play a conserved and central role in control of leaf flatness, size, shape and complexity. The loss of CIN function in snapdragon cin mutant disrupted leaf flatness and forms defective simple leaves with larger size and wavy margins $[11,12,56]$. In Arabidopsis, CIN-like TCPs have highly redundant and additive roles in regulating the morphogenesis of simple leaves (Figure 2). The Arabidopsis tcp single mutants produced leaves with no obvious differences from wild-type control. However, disruption of TCP4 and TCP10 had already led to larger and curled leaves. The high-order multiple CIN-like tcp mutants caused even severer leaf curvature and wavier leaf margins in a dose-dependent manner [53,57-59], indicating that the activity of CIN-like TCPs is pivotal for shaping leaf forms. The CIN-like TCP homolog in turnip (Brassica rapa), BrrTCP2, has conserved function in control of leaf size and morphology. Overexpression of BrrTCP2 reduced the leaf size of wild-type Arabidopsis and restored the leaf morphology of the Arabidopsis multiple mutant tcp 2 tcp 4 tcp10 [60]. In the regulation of leaf morphology, CIN-like TCPs repress the activity of leaf marginal meristem which determines leaf serrations in simple leaves or complexity of compound leaves in different plants. In lettuce (Lactuca sativa), the Empire type cultivars have more serrated leaves than the Salinas type cultivars. The molecular base is that Empire type cultivars carry a retrotransposable element inserted in the upstream of LsTCP4 gene, causing lower expression level of LsTCP4 than that in the Salina type cultivars. The downregulation of LsTCP4 by the insertion led to the severer leaf serration in Empire type cultivars [61]. However, differential expression analysis between broad- and curly-leaved plants of Cichorium endivia, a close relative of L. sativa that also displayed wavy or serrated leaves, did not identify TCP4-like homologous genes as differentially expressed in leaves with different morphologies, and the two transcripts were abundant in both leaf types [62]. Tomato forms compound leaves regulated by LACEOLATE (LA) homologous to CIN-like $T C P$ s. Downregulation of $L A$ generated more and larger leaflets, causing super-compound leaves. On the contrary, overexpression of $L A$ resulted in the compound leaves turning into simple leaves [63-65]. CPTCP1 in cyclamen (Cyclamen persicum) is a homolog of CIN-like TCPs. Disruption of TCP function by a dominant repressor in which the ethylene-responsive element binding factor-associated amphiphilic repression (EAR) repression domain (SRDX) was fused to CpTCP1 caused irregular protrusions of acicular and branched shapes in the leaf margins [66]. CIN-like TCPs also regulate the leafy head of Chinese cabbage (Brassica rapa). Altering the spatio-temporal expression patterns of BrpTCP4 led to a cylindrical head shape from a round one [67]. Furthermore, the genetic manipulation of CIN-like TCP activity resulted in different sizes and shapes of leaves in both simple and compound leaves $[64,68]$. These findings indicate that CIN-like TCPs are central regulators of leaf morphology and that the tight control of the spatio-temporal TCP activity is fundamental in determining diverse leaves in different species. 
CIN-like TCPs also modulate the development of organs homologous to leaves such as petals. The Arabidopsis single mutant tcp5 produces wider petals than the wild-type control [69]. Moreover, the 35S:miR-3TCP transgenic plants in which an artificial miRNA targeting to TCP5, TCP13, and TCP17 was expressed to knock down the three genes generate petals with even increased width from tip to base [69]. Besides TCP5-like CIN-TCPS which was identified to determine petal size, the other five CIN-like TCP genes targeted by miRNA319 also played vital roles in control of petal growth. The mutant carrying a loss-of-function mutation in miR319a (named as MiR319a ${ }^{129}$ ) exhibited narrow petals and sterile anthers, indicating that CIN-like TCPs not only inhibit the growth of petal [70], but also play an essential role in plant fertility. The overexpression of the miR319-resistant form of TCP4 by a petal-specific promoter rescued the narrow petals in MiR319a ${ }^{129}$ mutant [70,71]. CIN-like TCPs also modify the morphology of petals besides petal sizes. Expression of a dominant repressor in which TCP3 was fused to an EAR motif to disrupt the function of TCPs resulted in curled petals in Arabidopsis. Expression of other CIN-like TCP chimeric repressors also caused curled petals [72]. The function of CIN-like TCPs in regulating petal development is conserved among different species. For examples, the introduction of chimeric repressors of Arabidopsis CIN-like TCPs in Chrysanthemum morifolium or Ipomoea nil also led to similar wavy and serrated petals $[73,74]$. Suppression of TCP functions by expression of chimeric repressors of CPTCP1 homologous to Arabidopsis TCP3 in C. persicum caused ruffled petals [66].

At the cellular level, CIN-like TCPs regulate cell proliferation, cell elongation or expansion and cell differentiation. During leaf and petal development, CIN-like TCPs inhibit cell proliferation and promote cell differentiation. Disruption of CIN-like TCPs prolong the leaf cell proliferation in the leaf blade with more rapid growth in the margin than in the center of blade, leading to the increased number of pavement cells and wavy margins [11,12,35,58,59,75]. As specialized epidermal cells, trichomes are also regulated by CIN-like TCP transcription factors. CIN-like TCPs suppress the trichome differentiation and subsequent trichome branching. The numbers of trichomes and trichome branches were both significantly increased in jaw-D and tcp 2 tcp 4 tcp 10 mutants, but were decreased in TCP4 overexpression lines [76]. The function of CIN-like TCPs is also conserved in the regulation of trichome formation. Overexpression of miR319a in Populus tomentosa resulted in higher density of trichomes on the leaf surface when compared with that of wild-type control. When the functions of CIN-like TCPs were enhanced by inhibiting the roles of miR319, the number of trichomes was largely decreased [77]. Cotton fibers are specific trichome types on the seed epidermis. The constitutive overexpression of GhTCP4 homologous to Arabidopsis TCP4 in upland cotton (Gossypium hirsutum) repressed the elongation of cotton fiber [78]. However, CIN-like TCPs positively regulate hypocotyl cell elongation in Arabidopsis. Induction of CIN-like TCPs using mTCP4-GR in which TCP4 fusion with rat glucocorticoid receptor (GR) by dexamethasone (DEX) treatment in transgenic lines significantly increased the length of hypocotyl cells (Figure 2) [79]. Overexpression of TCP5-like CIN-TCPs led to the significant increase of hypocotyl under shade, high temperature or under normal growth conditions (Figure 2) [14]. In consistence with the results, the tcp5 tcp 13 tcp 17 triple mutant displayed short hypocotyls [14]. These findings demonstrate that CIN-like TCPs control cell proliferation, elongation and differentiation in a specific cell type-dependent manner at different context.

CIN-like TCPs are reported to be essential for regulating other biological processes. For examples, CIN-like TCPs facilitate the transition from vegetative to reproductive growth. The flowering time of $c i n$-like tcp multiple mutants was significantly postponed, while overexpression of TCP4 led to early flowering in Arabidopsis [80]. The tomato LA gene belonging to CIN-like TCP group controls flowering as well [81]. In addition, CIN-like TCPs participate in developmental plasticity in response to biotic stresses in Arabidopsis and rice. CIN-like TCPs are also implicated in the typical morphological alterations caused by infection of phytopathogens such as phytoplasmas in Arabidopsis [43-45]. Rice ragged stunt virus (RRSV) downregulated rice TCP21 belonging to miR319-targeted CIN-like TCPs by up-regulating the expression of miR319 gene. Overexpression of TCP21 increased the rice resistance to RRSV [82]. 


\section{Light Regulates CIN-Like TCP Transcription Factors}

Light is a critical environmental stimulus affecting plant development and growth including cotyledon opening, hypocotyl elongation and flowering [83-86]. When seeds germinate in dark under soil and then the seedlings grow out with exposure to light in nature, plants undergo an important morphological change from skotomorphogenesis to photomorphogenesis including cotyledon opening and inhibition of hypocotyl elongation $[83,87,88]$. The bHLH transcription factors PHYTOCHROME-INTERACTING FACTORs (PIFs) including PIF3 are central regulators in promoting skotomorphogenesis by suppressing cotyledon opening and the elongation of hypocotyl $[89,90]$. However, the molecular mechanisms of light-induced cotyledon opening are not well-known. Recently, CIN-like TCPs have been identified to participate in controlling light-induced cotyledon opening during photomorphogenesis (Figure 2). Interestingly, CIN-like TCP genes including TCP3, TCP4 and TCP10 are predominantly expressed in cotyledons under both light and dark growth conditions [13]. Why do CIN-like TCPs promote cotyledon opening in the light but not affect cotyledon closing in dark? Chromatin immunoprecipitation sequencing (ChIP-seq) and RNA sequencing (RNA-seq) analyses showed that TCP4 directly bind to the promoter regions of SMALL AUXIN UPREGULATED RNA (SAUR) genes including SAUR16 and SAUR50. The promoter regions of the SAUR genes are also directly targeted by PHYTOCHROME INTERACTING FACTOR3 (PIF3), a key component inhibiting cotyledon opening. The molecular mechanism is that the accumulated PIF3 in the dark represses the transactivation activity of TCP4 possibly by competing the binding to the promoter regions of SAUR genes with TCP4 in the dark, while in the light PIFs are rapidly degraded and causing more TCP4 proteins to bind to the promoters of the SAUR genes and to upregulate their expression to promote cotyledon opening (Figure 2) [86]. However, PIF3 does not interact with TCP4 in this process. The exact mechanism by which PIF3 inhibits TCP4 binding to the promoter regions of SAUR genes is still an open question.

In addition to controlling the light-regulated cotyledon opening in plant photomorphogenesis, CIN-like TCPs also participate in the regulation of light-regulated hypocotyl elongation under shade. The shade avoidance syndrome (SAS) of plants caused by neighboring shade or low ratio of red light to far red light (R:FR) includes long hypocotyl, elongated leaf petiole, reduced shoot branches and early flowering [91]. It is known that shade or low R:FR upregulates the expression level of $B R C 1$ or TB1 belonging to CYC/TB1-like TCP subgroup [37], while recently TCP5-like CIN-TCPs has been reported to regulate the rapid growth of hypocotyl in response to shade (Figure 2) [92]. The hypocotyl elongation of the triple mutant tcp $5 t c p 13 t c p 17$ was insensitive to shade, while overexpression of TCP17 led to longer hypocotyls under shade or white light. TCP17 is an unstable protein which is stabilized by shade. When plants were transferred from shade to white light, TCP17 was degraded and the degradation were inhibited by treatment with the 26S proteasome inhibitor MG132 [92]. This result indicates that white light promotes the degradation of TCP17 via the $26 \mathrm{~S}$ proteasome, while shade inhibits the process (Figure 2). Interestingly, the transcriptional level of TCP17 was rapidly downregulated by shade in reverse, indicating accumulation of TCP17 under shade is dependent on the post-transcriptional regulation [92]. It will be very interesting to identify the E3 ligase mediating the degradation of TCP17 under white light and the molecular mechanisms of suppression of the TCP17 degradation machinery by shade.

\section{High Temperature Regulates CIN-Like TCP Transcription Factors}

Ambient temperature is one of the most important environmental factors governing plant behavior. Plants adopt a series of morphological changes called thermomorphogenesis in adaptation to high temperature $[93,94]$. Thermomorphogenesis includes leaf hyponastic growth, petiole elongation and hypocotyl elongation [93]. TCP5-like CIN-TCPs have recently been identified to act as key factors in positively regulating plant thermomorphogenesis. High temperature not only induces the expression of TCP5, TCP13 and TCP17 genes at the transcriptional level, but also stabilizes the protein of TCP5-like CIN-TCPs at the post-transcriptional level in Arabidopsis (Figure 2) [14,95]. 
Interestingly, high temperature treatment regulates both the expression level and the expression pattern of TCP5. When TCP5pro-GUS transgenic lines in which GUS reporter gene was driven by TCP 5 promoter was treated under high temperature, the GUS staining was strengthened in the hypocotyls and cotyledons, and at the same time was shifted from the leaf blades to petioles, in consistence with the leaf trait of thermomorphogenesis with elongated petioles and reduced areas of blades [14]. High temperature also up-regulates the expression of PIF4 which is the first key factor identified in control of plant thermomorphogenesis $[96,97]$. TCP5 protein not only directly bound to the promoter region of PIF4 gene to increase its expression level [14], but also interacted with PIF4 at the protein level [14]. Moreover, TCP17 protein interacted with the blue light receptor CRYTOCHROME1 (CRY1) at lower temperature to block the activity of TCP17. High ambient temperature increased the protein stability of TCP17 and led to the release of TCP17 from TCP17-CRY1 complex, promoting the interactions between TCP17 and PIF4 [93]. The interactions between PIF4 with TCP5 or TCP17 synergistically promoted the expression of a lot of common downstream genes including PRE1 and YUC8, thus enhancing plant thermomorphogenesis (Figure 2) [14,95]. Accordingly, overexpression of CIN-like TCP5 gene led to constitutive thermomorphogenesis, while the hypocotyls and petioles of tcp5 tcp 13 tcp 17 were shorter than that of wild-type control under normal temperature or high temperature [14,95]. It is worth mentioning that although PIF4 is homologous to PIF3 which is a key regulator in photomorphogenesis [86], they use different mechanisms to regulate the activity of CIN-like TCPs. PIF3 do not interact with TCP4, but inhibits the binding activity of TCP4 to the promoter of their downstream genes in an unknown way under dark [86]. Adversely, PIF4 interacts with TCP5-like CIN-TCPs and obviously strengthened their transactivation activity in activating the downstream genes $[14,95]$. These results demonstrate that high temperature regulates the function of TCP5-like CIN-TCPs which positively regulate plant thermomorphogenesis by a different mechanism underlying the regulation of cotyledon opening by TCP4 in Arabidopsis. However, the transcription factors and E3 ligases that are responsible for regulating the expression of TCP5-like CIN-TCPS and the stability of their products under different ambient temperatures need to be further identified.

\section{Phytoplasmas Regulate CIN-Like TCP Transcription Factors}

Phytoplasmas are phytopathogens transmitted by insects and infect a wide range of plant species, causing great economic losses in agriculture $[47,98]$. Like the most pathogens, phytoplasmas produce effectors to alter the host-pathogen interface in facilitating their growth during infection [47]. The effectors cause some typical changes of plant morphology including overgrowth of lateral branches, altered leaf shape and sterile flowers [98]. The aster yellows phytoplasma witches' broom (AY-WB) strain infect a wide range of dicot and monocot species [47,48]. The secreted AY-WB protein 11 (SAP11) is a virulence nuclear effector with a nuclear localization signal at its $\mathrm{N}$-terminus. Overexpression of SAP11 in Arabidopsis produced serrate and wavy leaves almost identical to those of jaw-D and the multiple cin-like tcp mutants [48]. SAP11 interacts with CIN-like TCP proteins [48], leading to the TCP degradation which is not inhibited by the $26 \mathrm{~S}$ proteasome inhibitor epoxomicin or protease inhibitor cocktail (Figure 2). This indicates that the SAP11-mediating TCP protein degradation is not through ubiquitin-26S proteasome pathway [48]. Because CIN-like TCPs positively regulate the expression of LOX2 gene by directly binding to its promoter [53], the overexpression of SAP11 caused the downregulation of the LOX2 gene and reduced the production of jasmonic acid (JA) in both Arabidopsis and tobacco (Nicotiana benthamiana), facilitating the infection of phytoplasmas [47,49]. The SAP11 protein homologs in different phytoplasmas strains displayed the varied abilities in control of the stability of CIN-like TCPs. These strains include AY-WB, onion yellow strain M (OY-M), peanut pupurea witches' broom (PnWB), Candidatus phytoplasmas mali (CaPM) [49]. When SAP11 homologs were co-expressed with CIN-like TCPs in tobacco, the abundance of TCP proteins were measured to determine the abilities of SAP11 proteins in mediating TCP degradation [49]. The results showed that SAP11 ${ }_{\mathrm{AYWB}}$ had the strongest ability to mediate the degradation of TCP2, TCP3, TCP4, TCP5, TCP10 and TCP24, while SAP11 $1_{\mathrm{CaPM}}$ only mediated the degradation of TCP2 and TCP10 with lower ability 
than SAP11 $1_{\mathrm{AYWB}}$. SAP11 $1_{\mathrm{PnWB}}$ and SAP11 $1_{\mathrm{OYM}}$ only exhibited a weak ability to destabilize TCP2 [45]. The SAP11 homolog from the Maize Bushy Stunt Phytoplasmas ( $\left(\mathrm{SP}_{\mathrm{MBSP}}\right)$ have been shown to only interact with CYC/TB1-like TCPs, but not any members of CIN-like TCPs in maize [46]. Accordingly, the MBSP-infected maize showed overgrowth of tillers controlled by the CYC/TB1-like TCPs, but not had any effects on the morphology of leaves [46]. Similarly, SWP1 which is a SAP11-like phytoplasmas effector from wheat blue dwarf phytoplasma interacted with BRC1 and mediate the degradation of BRC1 when SWP1 was overexpressed in Arabidopsis [50]. These findings indicate that the effector SAP11 proteins from different phytoplasmas strains have different specificity in promoting the degradation of TCPs. As the SAP11 protein have no protease activity, the mechanisms underlying SAP11-mediated TCP degradation remains to be further discovered [48].

\section{6. miRNAs Regulate CIN-Like TCP Transcription Factors}

miRNAs are small RNAs that recognize targeting mRNA via base pairing to the highly complementary binding sites and suppress the stability and translation of mRNAs [99,100]. A subset of CIN-like TCP genes contains a miR319-targeting sequence at the 3 '-terminus of transcripts in almost all angiosperm groups $[13,63]$. The Arabidopsis jagged and wavy-Dominant (jaw-D) mutant was first identified from a collection of activation tagging mutants by forward genetics [13]. The mutant jaw- $D$ displayed a predominant phenotype with the serrated and curved leaves $[13,101]$. Further analysis showed that T-DNA with four cauliflower mosaic virus (CaMV) $35 \mathrm{~S}$ enhancer was inserted in neighboring region of MIRNA gene MIR319a in jaw-D. The expression of miR319a was activated and the target $C I N$-like TCP genes including TCP2, TCP3, TCP4, TCP10 and TCP24 were significantly downregulated in the mutant, suggesting that the transcript abundance of the corresponding TCP genes was regulated by miR319a (Figure 3) [13]. The overexpression of miR319 also caused epinastic cotyledons, more trichomes, defective secondary cell wall biosynthesis and venation patterning, a modest delay in flowering, crinkled petals, short stamen, reduced male fertility and crinkled fruits by downregulating CIN-like TCP genes [42,70,102-104]. Arabidopsis genome contains three MIR319 genes including MIR319a, MIR319b, and MIR319c which have highly redundant function in control of the abundance of CIN-like TCP transcripts [70]. However, the three MIR319 genes also showed largely non-overlapping expression patterns revealed by GUS reporter analysis in plants, suggesting that they may have distinct roles in control of TCP abundance in a temporal and spatial manner during plant development [70]. During leaf development, the MIR319a gene is only expressed at the stipules, which is completely complementary to the expression pattern of MIR319c that the highest expression level is detected at the basal region of leaf primordia and young leaves, indicating the functional divergences between the two genes. MIR319b is only expressed in the sepal and stamen abscission zones of inflorescences at the reproductive stage [70]. MIR319a and MIR319c have partially spatiotemporal overlapping expression patterns during early inflorescence development [70]. Though the GUS activity for promoter analysis of MIR319b was not detected in leaves, the mir319b single mutant moderately reduced the size of leaf serrations, and mir319a/b double mutant almost entirely suppressed serration formation [59], suggesting that MIR319b is essential for leaf development with a possible low expression level in leaves.

miR319 is a conserved and ancient plant miRNA family and plays important roles in plant morphological adaptation to environmental conditions by targeting TCP for degradation. The miR319 and miR159 share highly similarity in mature miRNA sequence, secondary structure, conservation pattern and biogenesis in Arabidopsis. miR319 and miR159 are proposed to evolve from a common ancestor in land plants [105]. miR159 did not induce the cleavage of TCP mRNAs due to the specificity of sequences, while miR319 mediated the cleavage of MYB33 and MYB65 mRNA, which are pivotal targets of miR159 [101,105]. Two miR319 copies were identified in the genome of M. polymorpha, which also contains two MpTCP genes [106]. However, the two MpTCP genes have no possible miR319-targeting site and one target of miR319 was identified as MpMYB33 [106,107]. In Physcomitrella 
and Selaginella, the TCP genes also have no miR319-targeting sites [108-110], indicating that miR319 regulation of CIN-like TCP possibly evolve after the divergence of lycophytes and euphyllophytes.

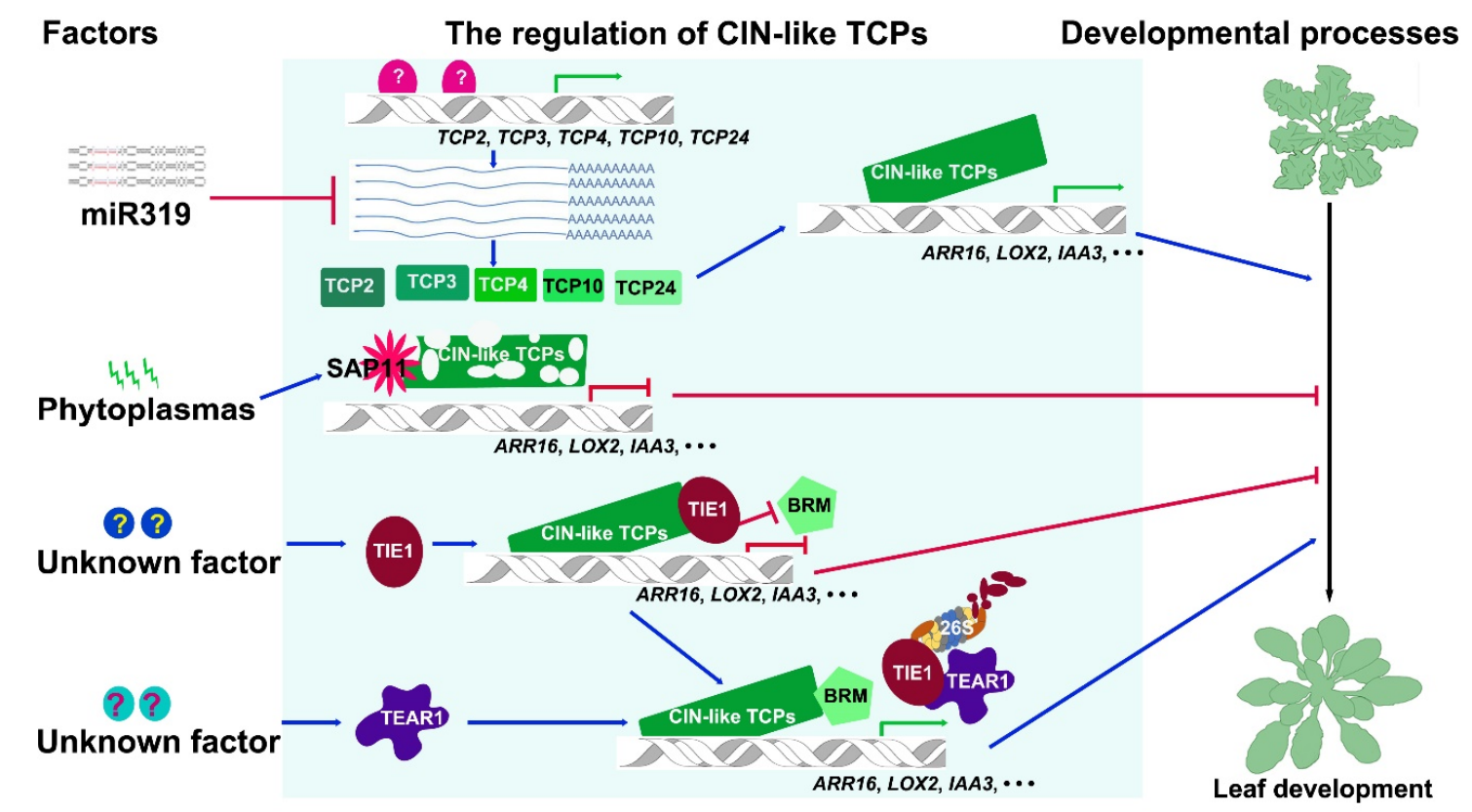

Figure 3. An overview of the regulation mechanisms of CIN-like TCP transcription factors during leaf development. The external stimuli and internal factors are summarized at the left column. The schematic diagram includes the regulation mechanisms of CIN-like TCPs at the transcriptional level, at the post-transcriptional level, and at the protein level. The arrows directly pointing on the double helix symbols indicate transcriptional regulations. The arrows pointing to the proteins indicate the regulations of protein stabilities or antagonistic functions. The proteins related with the " $26 \mathrm{~S}^{\text {" symbols }}$ indicate protein degradation through the ubiquitin-26S proteasome pathway. The blue arrows represent the positive regulation, and the red arrows with dash-headed ends indicate the negative regulation. The green arrows and red dash-headed ends at the double-helix icons indicates the activation and repression of gene expression, respectively. All the unknown factors are indicated with question marks. R:FR, red light: far red light ratio; YUCs, YUCCAs; LOX2, LIPOXYGENASE 2; SAP11, SECRETED AY-WB PROTEIN 11; ARR16, ARABIDOPSIS RESPONSE REGULATOR 16; IAA3, INDOLE-3-ACETIC ACID INDUCIBLE 3; BRM, BRAHMA; TIE1, TCP INTERACTOR CONTAINING EAR MOTIF PROTEIN 1; TEAR1, TIE1-ASSOCIATED RING-TYPE E3 LIGASE 1.

\section{Chromatin Remodeling Complexes Regulate the Activity of CIN-Like TCPs}

The activity of CIN-like TCPs is controlled by chromatin remodeling complexes including SWITCH/SUCROSE NONFERMENTING (SWI/SNF) complex and TCP INTERACTOR CONTAINING EAR MOTIF PROTEIN 1 (TIE1)-TOPLESS (TPL)/TOPLESS-RELATED (TPR) complex at the protein level (Figure 3). SWI/SNF complexes use ATPase to provide the energy in deciding the nucleosome position conformation and thus determining the accessibility of chromatin [111]. BRAHMA (BRM) encodes a SWI/SNF ATPase in Arabidopsis [112-114]. The hypomorphic mutations in BRM suppressed the phenotypes including fewer trichomes and smooth margins in TCP4 overexpression lines [114]. And the hypomorphic brm mutants produced curled leaves and delayed leaf maturation resembling the multiple cin-like tcp mutants, indicating that BRM promotes the activity of CIN-like TCPs (Figure 3) [114]. BRM interacts with TCP4 and together bind to the promoter region of type A ARABIDOPSIS RESPONSE REGULATOR (ARR) gene ARR16 to promote the expression of ARR16 (Figure 3) [115]. The modulation of CIN-like TCP activity by BRM provides a fine regulation of leaf sensitivity to the phytohormone cytokinin (CK) during leaf development. 
Compared with the positive regulation of CIN-like TCP activity mediated by BRM, TIE1-TPL/TPR complexes repressed CIN-like TCP activity by recruiting histone deacetylases (HDA) (Figure 3) [116]. TIE1 was identified to regulate TCP activity by analyzing a gain-of-function mutant tie1-D obtained by screening a collection of activation tagging mutants for leaf-defective ones. Overexpression of TIE1 in tie1-D or in transgenic plants using CaMV 35S promoter to drive TIE1 all led to curled and serrated leaves that are observed in the multiple $c i n-$ like $t c p$ mutants [116]. TIE1 encodes a transcriptional repressor containing a typical EAR motif at the C-terminal end. Indeed, TIE1 has transcriptional repression activity and directly interacts with the corepressor TPL/TPRs through EAR motif. TIE1 also interacts with CIN-like TCPs via the N-terminal domain. Consequently, TIE1 suppresses the activity of CIN-like TCPs by acting as a bridge connecting corepressor TPL/TPRs with CIN-like TCPs during leaf development (Figure 3) [116]. Interestingly, TIE1 also interacted with BRC1 belonging to CYC/TB1-like TCP group [40]. TIE1 had overlapping expression pattern with BRC1 in young axillary buds and overexpression of TIE1 resulted in excessive branches, indicating that TIE1 also represses the activity of BRC1 during shoot branching [40]. The function of TIE1 is conserved in controlling shoot branching in cotton (Gossypium hirsutum) [117]. GhTIE1 interacted with CYC subclade proteins GhBRC1, GhBRC2, and GhTCP13 in vivo. Silencing of GhTIE1 in cotton seriously decreased shoot branching [117]. A similar mechanism in suppression of CIN-like TCP activity is mediated by SPOROCYTELESS/NOZZLE (SPL/NZZ) during ovule development [118]. SPL/NZZ is a key regulator responsible for promoting the differentiation of megasporocytes. No megasporocytes were formed in the ovules of $s p l / n z z$ mutants. SPL/NZZ also contains a typical EAR repressor motif at the C-terminal domain and has the transcriptional repression activity. SPL/NZZ uses C-terminal EAR motif to interact with TPL/TPRs and uses its N-terminal domain to interact with CIN-like TCPs [118]. Overexpression of SPL in T-DNA activation tagging mutant spl-D caused the defective ovule arrangement in ovaries resembling to that of the multiple $\operatorname{cin}$-like tcp mutants. Consistently, overexpression of the CIN-like $T C P s$ led to no megasporocytes resembling the phenotype of $s p l$ loss-of-function mutants [118]. These results indicate that SPL inhibits the activity of CIN-like TCPs in a way similar to TIE1 by connecting TPL/TPR corepressors with CIN-like TCPs.

The regulation of CIN-like TCP activity by TIE1, SPL or BRM during leaf or ovule development is parallel to the regulation of key regulators in auxin signaling. The EAR motif-containing AUXIN (AUX)/INDOLE-3-ACETIC ACID (IAA) repressors mediate auxin signaling by recruiting TPL/TPRs to suppress the activity of AUXIN RESPONSE FACTORS (ARFs) [119-121]. Auxin triggers the degradation of AUX/IAA via 26S proteasome, the released ARFs such as MONOPTEROS (MP) bind to SWI/SNF chromatin remodeling ATPases BRM to promote the accessibility of chromatin and the expression of downstream genes. Interestingly, TIE1 is also an unstable protein as AUX/IAA repressors and the degradation of TIE1 is mediated by an E3 ligase TIE1-ASSOCIATED RING-TYPE E3 LIGASE1 (TEAR1) (Figure 3) [122]. Disruption of TEAR1 leads to serrated and curled leaves similar to that observed in the multiple cin-like tcp mutants and tie1-D [122]. These findings suggest that TEAR1 indirectly regulates the activity of CIN-like TCPs by switching the interactors of CIN-like TCPs from TIE1 to BRM (Figure 3), thus changing the chromatin state to control leaf development. However, the signals triggering the TIE1 degradation to release the suppression of CIN-like TCPs by TEAR1 need to be further identified.

\section{Concluding Remarks and Perspectives}

CIN-like TCPs are key transcription factors essential for plant growth and development in response to environmental cues and internal signals. The temporal and spatial activity of CIN-like TCPs determines cell proliferation, expansion and differentiation of cells in different organs in shaping plant morphology at various developmental stages. Consequently, the fine-tuning of CIN-like TCP activity is critical for plant developmental plasticity. At the transcriptional level, CIN-like TCPS are dynamically and specifically expressed in organs and also are induced by environmental signals including light and temperature $[14,92,95]$. However, the upstream regulation which determines the 
dynamic expression pattern and induction of $C I N$-like TCP genes are insufficient. The transcriptional repressor RABBIT EARS (RBE) has been reported to decreased the expression of TCP4, TCP5, TCP13 and TCP17 in promoting petal growth and TCP4 and TCP5 are possibly direct targets of RBE [69,71]. More studies on detailed analysis of the promoter regions of CIN-like TCPS are necessary for elucidating other upstream regulators, especially the direct regulators. The truncated promoters can be used to drive reporters in determining the minimal regions required for the expression patterns of CIN-like $T C P$ s. Transcription factors directly interacting with the promoters of $C I N$-like TCPS could be identified by yeast-one-hybrid screening.

CIN-like TCPs are central for regulating biosynthesis and signaling of different phytohormones including auxin, JA and brassinosteroid (BR) $[53,123,124]$. However, little is known about how phytohormones regulate CIN-like TCPs. It has been shown that auxin, gibberellin (GA), strigolactone (SL) and cytokinin (CK) regulate $B R C 1$ belonging to $C Y C / T B 1$-like TCP group of class II TCPs [36,125,126]. The decreased auxin level by overexpression of IAA CARBOXYL METHYLTRANSFERASE1 (IAMT1) which converted IAA to methyl-IAA ester led to curly leaves and reduced the expression level of some CIN-like TCPS [127], indicating that auxin positively regulates CIN-like TCPS at the transcriptional level. Further studies are needed to determine whether other plant hormones and environmental signals except light and temperature could possibly regulate CIN-like TCPs and how these signals could be integrated to control the activity of CIN-like TCPs.

At the post-transcriptional level, the miR319-TCP regulation module is conserved and widely studied in several plant species $[13,63]$. Could the other miRNAs targeting CIN-like TCPs exist in different plant species? which are those transcription factors deciding the expression level and pattern of MIR319 genes? These questions are still open.

At the protein level, we know little about the degradation mechanisms of CIN-like TCPs mediated by $26 \mathrm{~S}$ proteasome or other protein degradation pathways. The regulation mechanisms of CIN-like TCPs by class I TCP transcription factors and other interacting proteins are still largely unknown. It is still a challenge to thoroughly understand the shaping of plant morphology controlled by the CIN-like TCP-centered network under various environmental and developmental conditions in Arabidopsis and the other plant species.

Author Contributions: J.L. and G.Q. wrote the manuscript; J.L. and G.Q. have read and agreed to publish the version of the manuscript. All authors have read and agreed to the published version of the manuscript.

Funding: This research was supported by the National Science Fund for Distinguished Young Scholars of China (Grant No. 31725005) and the Science Fund for the Creative Research Groups of the National Natural Science Foundation of China (Grant No. 31621001).

Acknowledgments: Because of space constraints, we apologize to all colleagues whose work and publications have not been mentioned and cited.

Conflicts of Interest: The authors declare no conflict of interest.

\section{References}

1. Gaillochet, C.; Lohmann, J.U. The never-ending story: From pluripotency to plant developmental plasticity. Development 2015, 142, 2237-2249. [CrossRef]

2. Doebley, J.; Stec, A.; Gustus, C. Teosinte Branched1 and the origin of maize - evidence for epistasis and the evolution of dominance. Genetics 1995, 141, 333-346. [PubMed]

3. Luo, D.; Carpenter, R.; Vincent, C.; Copsey, L.; Coen, E. Origin of floral asymmetry in Antirrhinum. Nature 1996, 383, 794-799. [CrossRef] [PubMed]

4. Kosugi, S.; Ohashi, Y. PCF1 and PCF2 specifically bind to cis elements in the rice proliferating cell nuclear antigen gene. Plant Cell 1997, 9, 1607-1619. [PubMed]

5. Doebley, J.; Stec, A.; Hubbard, L. The evolution of apical dominance in maize. Nature 1997, 386, 485-488. [CrossRef]

6. Luo, D.; Carpenter, R.; Copsey, L.; Vincent, C.; Clark, J.; Coen, E. Control of organ asymmetry in flowers of Antirrhinum. Cell 1999, 99, 367-376. [CrossRef] 
7. Cubas, P.; Lauter, N.; Doebley, J.; Coen, E. The TCP domain: A motif found in proteins regulating plant growth and development. Plant J. 1999, 18, 215-222. [CrossRef]

8. Kosugi, S.; Ohashi, Y. DNA binding and dimerization specificity and potential targets for the TCP protein family. Plant J. 2002, 30, 337-348. [CrossRef]

9. Martin-Trillo, M.; Cubas, P. TCP genes: A family snapshot ten years later. Trends Plant Sci. 2010, 15, 31-39. [CrossRef]

10. Howarth, D.G.; Donoghue, M.J. Phylogenetic analysis of the "'ECE” (CYC/TB1) clade reveals duplications predating the core eudicots. Proc. Natl. Acad. Sci. USA 2006, 103, 9101-9106. [CrossRef]

11. Nath, U.; Crawford, B.C.W.; Carpenter, R.; Coen, E. Genetic control of surface curvature. Science 2003, 299, 1404-1407. [CrossRef] [PubMed]

12. Crawford, B.C.W.; Nath, U.; Carpenter, R.; Coen, E.S. CINCINNATA controls both cell differentiation and growth in petal lobes and leaves of antirrhinum. Plant Physiol. 2004, 135, 244-253. [CrossRef] [PubMed]

13. Palatnik, J.F.; Allen, E.; Wu, X.; Schommer, C.; Schwab, R.; Carrington, J.C.; Weigel, D. Control of leaf morphogenesis by microRNAs. Nature 2003, 425, 257-263. [CrossRef] [PubMed]

14. Han, X.; Yu, H.; Yuan, R.; Yang, Y.; An, F.; Qin, G. Arabidopsis transcription factor TCP5 controls plant thermomorphogenesis by positively regulating PIF4 activity. Iscience 2019, 15, 611-622. [CrossRef]

15. Katoh, K.; Rozewicki, J.; Yamada, K.D. MAFFT online service: Multiple sequence alignment, interactive sequence choice and visualization. Brief. Bioinform. 2019, 20, 1160-1166. [CrossRef]

16. Minh, B.Q.; Schmidt, H.A.; Chernomor, O.; Schrempf, D.; Woodhams, M.D.; von Haeseler, A.; Lanfear, R. IQ-TREE 2: New models and efficient methods for phylogenetic inference in the genomic era. Mol. Biol. and Evol. 2020, 37, 1530-1534. [CrossRef]

17. Liu, M.M.; Wang, M.M.; Yang, J.; Wen, J.; Guo, P.C.; Wu, Y.W.; Ke, Y.Z.; Li, P.F.; Li, J.N.; Du, H. Evolutionary and comparative expression analyses of TCP transcription factor gene family in land plants. Int. J. Mol. Sci. 2019, 20, 3591. [CrossRef]

18. Rensing, S.A.; Lang, D.; Zimmer, A.D.; Terry, A.; Salamov, A.; Shapiro, H.; Nishiyama, T.; Perroud, P.F.; Lindquist, E.A.; Kamisugi, Y.; et al. The Physcomitrella genome reveals evolutionary insights into the conquest of land by plants. Science 2008, 319, 64-69. [CrossRef]

19. Bowman, J.L.; Kohchi, T.; Yamato, K.T.; Jenkins, J.; Shu, S.Q.; Ishizaki, K.; Yamaoka, S.; Nishihama, R.; Nakamura, Y.; Berger, F.; et al. Insights into land plant evolution garnered from the Marchantia polymorpha genome. Cell 2017, 171, 287-304. [CrossRef]

20. Navaud, O.; Dabos, P.; Carnus, E.; Tremousaygue, D.; Herve, C. TCP transcription factors predate the emergence of land plants. J. Mol. Evol. 2007, 65, 23-33. [CrossRef]

21. Gubitz, T.; Caldwell, A.; Hudson, A. Rapid molecular evolution of CYCLOIDEA-like genes in Antirrhinum and its relatives. Mol. Bio. Evol. 2003, 20, 1537-1544. [CrossRef]

22. Chapman, M.A.; Leebens-Mack, J.H.; Burke, J.M. Positive selection and expression divergence following gene duplication in the sunflower CYCLOIDEA gene family. Mol. Bio. Evol. 2008, 25, 1260-1273. [CrossRef]

23. Mondragon-Palomino, M.; Trontin, C. High time for a roll call: Gene duplication and phylogenetic relationships of TCP-like genes in monocots. Ann. Bot. 2011, 107, 1533-1544. [CrossRef] [PubMed]

24. Horn, S.; Pabón-Mora, N.; Theuß, V.S.; Busch, A.; Zachgo, S. Analysis of the CYC/TB1 class of TCP transcription factors in basal angiosperms and magnoliids. Plant J. 2015, 81, 559-571. [CrossRef] [PubMed]

25. Citerne, H.L.; Reyes, E.; Le Guilloux, M.; Delannoy, E.; Simonnet, F.; Sauquet, H.; Weston, P.H.; Nadot, S.; Damerval, C. Characterization of CYCLOIDEA-like genes in Proteaceae, a basal eudicot family with multiple shifts in floral symmetry. Ann. Bot. 2017, 119, 367-378. [CrossRef] [PubMed]

26. Busch, A.; Deckena, M.; Almeida-Trapp, M.; Kopischke, S.; Kock, C.; Schuessler, E.; Tsiantis, M.; Mithoefer, A.; Zachgo, S. MpTCP1 controls cell proliferation and redox processes in Marchantia polymorpha. New Phytol. 2019, 224, 1627-1641. [CrossRef] [PubMed]

27. Floyd, S.K.; Bowman, J.L. The ancestral developmental tool kit of land plants. Int. J. Plant Sci. 2007, 168, 1-35. [CrossRef]

28. Koelsch, A.; Gleissberg, S. Diversification of CYCLOIDEA-like TCP genes in the basal eudicot families Fumariaceae and Papaveraceae s.str. Plant Biol. 2006, 8, 680-687. [CrossRef]

29. Damerval, C.; Le Guilloux, M.; Jager, M.; Charon, C. Diversity and evolution of CYCLOIDEA-like TCP genes in relation to flower development in Papaveraceae. Plant Physiol. 2007, 143, 759-772. [CrossRef] 
30. Bartlett, M.E.; Specht, C.D. Changes in expression pattern of the teosinte branched1-like genes in the Zingiberales provide a mechanism for evolutionary shifts in symmetry across the order. Am. J. Bot. 2011, 98, 227-243. [CrossRef]

31. Jabbour, F.; Cossard, G.; Le Guilloux, M.; Sannier, J.; Nadot, S.; Damerval, C. Specific duplication and dorsoventrally asymmetric expression patterns of Cycloidea-like genes in zygomorphic species of Ranunculaceae. PLoS ONE 2014, 9, e95727. [CrossRef] [PubMed]

32. Resentini, F.; Felipo-Benavent, A.; Colombo, L.; Blazquez, M.A.; Alabadi, D.; Masiero, S. TCP14 and TCP15 mediate the promotion of seed germination by gibberellins in Arabidopsis thaliana. Mol. Plant 2015, 8, 482-485. [CrossRef]

33. Tatematsu, K.; Nakabayashi, K.; Kamiya, Y.; Nambara, E. Transcription factor AtTCP14 regulates embryonic growth potential during seed germination in Arabidopsis thaliana. Plant J. 2008, 53, 42-52. [CrossRef] [PubMed]

34. Alvarez, J.P.; Furumizu, C.; Efroni, I.; Eshed, Y.; Bowman, J.L. Active suppression of a leaf meristem or chestrates determinate leaf growth. Elife 2016, 5, e15023. [CrossRef] [PubMed]

35. Challa, K.R.; Rath, M.; Nath, U. The CIN-TCP transcription factors promote commitment to differentiation in Arabidopsis leaf pavement cells via both auxin-dependent and independent pathways. PLoS Genet. 2019, 15, e1007988. [CrossRef] [PubMed]

36. Aguilar-Martinez, J.A.; Poza-Carrion, C.; Cubas, P. Arabidopsis BRANCHED1 acts as an integrator of branching signals within axillary buds. Plant Cell 2007, 19, 458-472. [CrossRef]

37. Gonzalez-Grandio, E.; Poza-Carrion, C.; Sorzano, C.O.S.; Cubas, P. BRANCHED1 promotes axillary bud dormancy in response to shade in Arabidopsis. Plant Cell 2013, 25, 834-850. [CrossRef]

38. Gonzalez-Grandio, E.; Pajoro, A.; Franco-Zorrilla, J.M.; Tarancon, C.; Immink, R.G.H.; Cubas, P. Abscisic acid signaling is controlled by a BRANCHED1/HD-ZIP I cascade in Arabidopsis axillary buds. Proc. Natl. Acad. Sci. USA 2017, 114, E245-E254. [CrossRef]

39. Wang, M.; Le Moigne, M.-A.; Bertheloot, J.; Crespel, L.; Perez-Garcia, M.-D.; Oge, L.; Demotes-Mainard, S.; Hamama, L.; Daviere, J.-M.; Sakr, S. BRANCHED1: A key hub of shoot branching. Front. Plant Sci. 2019, 10, 76. [CrossRef]

40. Yang, Y.; Nicolas, M.; Zhang, J.; Yu, H.; Guo, D.; Yuan, R.; Zhang, T.; Yang, J.; Cubas, P.; Qin, G. The TIE1 transcriptional repressor controls shoot branching by directly repressing BRANCHED1 in Arabidopsis. PLoS Genet. 2018, 14, e1007296. [CrossRef]

41. Ballester, P.; Navarrete-Gomez, M.; Carbonero, P.; Onate-Sanchez, L.; Ferrandiz, C. Leaf expansion in Arabidopsis is controlled by a TCP-NGA regulatory module likely conserved in distantly related species. Physiol. Planta. 2015, 155, 21-32. [CrossRef]

42. Bresso, E.; Chorostecki, U.; Rodriguez, R.E.; Palatnik, J.F.; Schommera, C. Spatial control of gene expression by miR319-regulated TCP transcription factors in leaf development. Plant Physiol. 2018, 176, 1694-1708. [CrossRef] [PubMed]

43. Balsemao-Pires, E.; Andrade, L.R.; Sachetto-Martins, G. Functional study of TCP23 in Arabidopsis thaliana during plant development. Plant Physiol. Biochem. 2013, 67, 120-125. [CrossRef] [PubMed]

44. Wu, J.-F.; Tsai, H.-L.; Joanito, I.; Wu, Y.-C.; Chang, C.-W.; Li, Y.-H.; Wang, Y.; Hong, J.C.; Chu, J.-W.; Hsu, C.-P.; et al. LWD-TCP complex activates the morning gene CCA1 in Arabidopsis. Nat. Commun. 2016, 7, 13181. [CrossRef] [PubMed]

45. Chang, S.H.; Tan, C.M.; Wu, C.-T.; Lin, T.-H.; Jiang, S.-Y.; Liu, R.-C.; Tsai, M.-C.; Su, L.-W.; Yang, J.-Y. Alterations of plant architecture and phase transition by the phytoplasma virulence factor SAP11. J. Exp. Bot. 2018, 69, 5389-5401. [CrossRef]

46. Pecher, P.; Moro, G.; Canale, M.C.; Capdevielle, S.; Singh, A.; MacLean, A.; Sugio, A.; Kuo, C.-H.; Lopes, J.R.S.; Hogenhout, S.A. Phytoplasma SAP11 effector destabilization of TCP transcription factors differentially impact development and defence of Arabidopsis versus maize. PLoS Pathog. 2019, 15, e1008035. [CrossRef]

47. Sugio, A.; Kingdom, H.N.; MacLean, A.M.; Grieve, V.M.; Hogenhout, S.A. Phytoplasma protein effector SAP11 enhances insect vector reproduction by manipulating plant development and defense hormone biosynthesis. Proc. Natl. Acad. Sci. USA 2011, 108, E1254-E1263. [CrossRef]

48. Sugio, A.; MacLean, A.M.; Hogenhout, S.A. The small phytoplasma virulence effector SAP11 contains distinct domains required for nuclear targeting and CIN-TCP binding and destabilization. New Phytol. 2014, 202, 838-848. [CrossRef] 
49. Tan, C.M.; Li, C.-H.; Tsao, N.-W.; Su, L.-W.; Lu, Y.-T.; Chang, S.H.; Lin, Y.Y.; Liou, J.-C.; Hsieh, L.-C.; Yu, J.-Z.; et al. Phytoplasma SAP11 alters 3-isobutyl-2-methoxypyrazine biosynthesis in Nicotiana benthamiana by suppressing NbOMT1. J. Exp. Bot. 2016, 67, 4415-4425. [CrossRef]

50. Wang, N.; Yang, H.; Yin, Z.; Liu, W.; Sun, L.; Wu, Y. Phytoplasma effector SWP1 induces witches' broom symptom by destabilizing the TCP transcription factor BRANCHED1. Mol. Plant Pathol. 2018, 19, 2623-2634. [CrossRef]

51. Danisman, S.; van der Wal, F.; Dhondt, S.; Waites, R.; de Folter, S.; Bimbo, A.; van Dijk, A.-J.; Muino, J.M.; Cutri, L.; Dornelas, M.C.; et al. Arabidopsis Class I and Class II TCP transcription factors regulate jasmonic acid metabolism and leaf development antagonistically. Plant Physiol. 2012, 159, 1511-1523. [CrossRef] [PubMed]

52. Koyama, T. A hidden link between leaf development and senescence. Plant Sci. 2018, 276, 105-110. [CrossRef] [PubMed]

53. Schommer, C.; Palatnik, J.F.; Aggarwal, P.; Chetelat, A.; Cubas, P.; Farmer, E.E.; Nath, U.; Weigel, D. Control of jasmonate biosynthesis and senescence by miR319 targets. PLoS Biol. 2008, 6, 1991-2001. [CrossRef]

54. Sarvepalli, K.; Nath, U. CIN-TCP transcription factors: Transiting cell proliferation in plants. Iubmb Life 2018, 70, 718-731. [CrossRef] [PubMed]

55. Nicolas, M.; Cubas, P. TCP factors: New kids on the signaling block. Curr. Opin. Plant Biol. 2016, 33, 33-41. [CrossRef] [PubMed]

56. Das Gupta, M.; Aggarwal, P.; Nath, U. CINCINNATA in Antirrhinum majus directly modulates genes involved in cytokinin and auxin signaling. New Phytol. 2014, 204, 901-912. [CrossRef]

57. Schommer, C.; Debernardi, J.M.; Bresso, E.G.; Rodriguez, R.E.; Palatnik, J.F. Repression of cell proliferation by miR319-regulated TCP4. Mol. Plant 2014, 7, 1533-1544. [CrossRef]

58. Koyama, T.; Mitsuda, N.; Seki, M.; Shinozaki, K.; Ohme-Takagi, M. TCP transcription factors regulate the activities of ASYMMETRIC LEAVES1 and miR164, as well as the auxin response, during differentiation of leaves in Arabidopsis. Plant Cell 2010, 22, 3574-3588. [CrossRef]

59. Koyama, T.; Sato, F.; Ohme-Takagi, M. Roles of miR319 and TCP transcription factors in leaf development. Plant Physiol. 2017, 175, 874-885. [CrossRef]

60. Du, J.; Hu, S.; Yu, Q.; Wang, C.; Yang, Y.; Sun, H.; Yang, Y.; Sun, X. Genome-wide identification and characterization of BrrTCP transcription factorsin Brassica rapa ssp rapa. Front. Plant Sci. 2017, 8, 1588. [CrossRef]

61. Seki, K.; Komatsu, K.; Tanaka, K.; Hiraga, M.; Kajiya-Kanegae, H.; Matsumura, H.; Uno, Y. A CIN-like TCP transcription factor (LsTCP4) having retrotransposon insertion associates with a shift from Salinas type to Empire type in crisphead lettuce (Lactuca sativa L.). Hortic. Res. 2020, 7, 15. [CrossRef] [PubMed]

62. Testone, G.; Baldoni, E.; Iannelli, M.A.; Nicolodi, C.; Di Giacomo, E.; Pietrini, F.; Mele, G.; Giannino, D.; Frugis, G. Transcription factor networks in leaves of Cichorium endivia: New insights into the relationship between photosynthesis and leaf development. Plants-Basel 2019, 8, 531. [CrossRef]

63. Ori, N.; Cohen, A.R.; Etzioni, A.; Brand, A.; Yanai, O.; Shleizer, S.; Menda, N.; Amsellem, Z.; Efroni, I.; Pekker, I.; et al. Regulation of LANCEOLATE by miR319 is required for compound-leaf development in tomato. Nat. Genet. 2007, 39, 787-791. [CrossRef] [PubMed]

64. Shleizer-Burko, S.; Burko, Y.; Ben-Herzel, O.; Ori, N. Dynamic growth program regulated by LANCEOLATE enables flexible leaf patterning. Development 2011, 138, 695-704. [CrossRef] [PubMed]

65. Burko, Y.; Shleizer-Burko, S.; Yanai, O.; Shwartz, I.; Zelnik, I.D.; Jacob-Hirsch, J.; Kela, I.; Eshed-Williams, L.; Ori, N. A Role for APETALA1/FRUITFULL transcription factors in tomato leaf development. Plant Cell 2013, 25, 2070-2083. [CrossRef] [PubMed]

66. Tanaka, Y.; Yamamura, T.; Oshima, Y.; Mitsuda, N.; Koyama, T.; Ohme-Takagi, M.; Terakawa, T. Creating ruffled flower petals in Cyclamen persicum by expression of the chimeric cyclamen TCP repressor. Plant Biotech. 2011, 28, 141-147. [CrossRef]

67. Mao, Y.; Wu, F.; Yu, X.; Bai, J.; Zhong, W.; He, Y. microRNA319a-targeted Brassica rapa ssp pekinensis TCP genes modulate head shape in Chinese cabbage by differential cell division arrest in leaf regions. Plant Physiol. 2014, 164, 710-720. [CrossRef]

68. Efroni, I.; Blum, E.; Goldshmidt, A.; Eshed, Y. A protracted and dynamic maturation schedule underlies arabidopsis leaf development. Plant Cell 2008, 20, 2293-2306. [CrossRef] 
69. Huang, T.; Irish, V.F. Temporal control of plant organ growth by TCP transcription factors. Curr. Biol. 2015, 25, 1765-1770. [CrossRef]

70. Nag, A.; King, S.; Jack, T. MiR319a targeting of TCP4 is critical for petal growth and development in Arabidopsis. Proc. Natl. Acad. Sci. USA 2009, 106, 22534-22539. [CrossRef]

71. Li, J.; Wang, Y.; Zhang, Y.; Wang, W.; Irish, V.F.; Huang, T. RABBIT EARS regulates the transcription of TCP4 during petal development in Arabidopsis. J. Exp. Bot. 2016, 67, 6473-6480. [CrossRef] [PubMed]

72. Koyama, T.; Furutani, M.; Tasaka, M.; Ohme-Takagi, M. TCP transcription factors control the morphology of shoot lateral organs via negative regulation of the expression of boundary-specific genes in Arabidopsis. Plant Cell 2007, 19, 473-484. [CrossRef] [PubMed]

73. Ono, M.; Hiyama, S.; Higuchi, Y.; Kamada, H.; Nitasaka, E.; Koyama, T.; Mitsuda, N.; Ohme-Takagi, M.; Sage-Ono, K. Morphological changes in Ipomoea nil using chimeric repressors of Arabidopsis TCP3 and TCP5. Plant Biotech. 2012, 29, 457-463. [CrossRef]

74. Narumi, T.; Aida, R.; Koyama, T.; Yamaguchi, H.; Sasaki, K.; Shikata, M.; Nakayama, M.; Ohme-Takagi, M.; Ohtsubo, N. Arabidopsis chimeric TCP3 repressor produces novel floral traits in Torenia fournieri and Chrysanthemum morifolium. Plant Biotech. 2011, 28, 131-140. [CrossRef]

75. Koyama, T.; Ohme-Takagi, M.; Sato, F. Generation of serrated and wavy petals by inhibition of the activity of TCP transcription factors in Arabidopsis thaliana. Plant Signal. Behav. 2011, 6, 697-699. [CrossRef] [PubMed]

76. Vadde, B.V.L.; Challa, K.R.; Sunkara, P.; Hegde, A.S.; Nath, U. The TCP4 transcription factor directly activates TRICHOMELESS1 and 2 and suppresses trichome initiation. Plant Physiol. 2019, 181, 1587-1599. [CrossRef] [PubMed]

77. Fan, D.; Ran, L.; Hu, J.; Ye, X.; Xu, D.; Li, J.; Su, H.; Wang, X.; Ren, S.; Luo, K. MiR319a/TCP module and DELLA protein regulate trichome initiation synergistically and improve insect defenses in Populus tomentosa. New Phytol. 2020. Available online: https://pubmed.ncbi.nlm.nih.gov/32270484/ (accessed on 8 April 2020).

78. Cao, J.F.; Zhao, B.; Huang, C.C.; Chen, Z.W.; Zhao, T.; Liu, H.R.; Hu, G.J.; Shangguan, X.X.; Shan, C.M.; Wang, L.J.Y.; et al. The miR319-targeted GhTCP4 promotes the transition from cell elongation to wall thickening in cotton fiber. Mol. Plant 2020. Available online: https://www.sciencedirect.com/science/article/ pii/S1674205220301416 (accessed on 16 May 2020).

79. Challa, K.R.; Aggarwal, P.; Nath, U. Activation of YUCCA5 by the transcription factor TCP4 integrates developmental and environmental signals to promote hypocotyl elongation in Arabidopsis. Plant Cell 2016, 28, 2117-2130. [CrossRef]

80. Liu, J.; Cheng, X.; Liu, P.; Li, D.; Chen, T.; Gu, X.; Sun, J. MicroRNA319-regulated TCPs interact with FBHs and PFT1 to activate CO transcription and control flowering time in Arabidopsis. PLoS Genet. 2017, 13, e1006833. [CrossRef]

81. Silva, G.F.F.; Silva, E.M.; Correa, J.P.O.; Vicente, M.H.; Jiang, N.; Notini, M.M.; Junior, A.C.; De Jesus, F.A.; Castilho, P.; Carrera, E.; et al. Tomato floral induction and flower development are orchestrated by the interplay between gibberellin and two unrelated microRNA-controlled modules. New Phytol. 2019, 221, 1328-1344. [CrossRef]

82. Zhang, C.; Ding, Z.; Wu, K.; Yang, L.; Li, Y.; Yang, Z.; Shi, S.; Liu, X.; Zhao, S.; Yang, Z.; et al. Suppression of jasmonic acid-mediated defense by viral-inducible microRNA319 facilitates virus infection in rice. Mol. Plant 2016, 9, 1302-1314. [CrossRef]

83. Chen, M.; Chory, J.; Fankhauser, C. Light signal transduction in higher plants. Annu. Rev. Genet. 2004, 38, 87-117. [CrossRef] [PubMed]

84. Feng, S.; Martinez, C.; Gusmaroli, G.; Wang, Y.; Zhou, J.; Wang, F.; Chen, L.; Yu, L.; Iglesias-Pedraz, J.M.; Kircher, S.; et al. Coordinated regulation of Arabidopsis thaliana development by light and gibberellins. Nature 2008, 451, 475-479. [CrossRef] [PubMed]

85. Song, Y.H.; Shim, J.S.; Kinmonth-Schultz, H.A.; Imaizumi, T. Photoperiodic flowering: Time measurement mechanisms in leaves. Annu. Rev. Plant Biol. 2015, 66, 441-464. [CrossRef] [PubMed]

86. Dong, J.; Sun, N.; Yang, J.; Deng, Z.; Lan, J.; Qin, G.; He, H.; Deng, X.W.; Irish, V.F.; Chen, H.; et al. The transcription factors TCP4 and PIF3 antagonistically regulate organ-specific light induction of SAUR genes to modulate cotyledon opening during de-etiolation in Arabidopsis. Plant Cell 2019, 31, 1155-1170. [CrossRef]

87. von Arnim, A.; Deng, X.W. Light control of seedling development. Annu. Rev. Plant Physiol. Mol. Biol. 1996, 47, 215-243. [CrossRef] 
88. Kami, C.; Lorrain, S.; Hornitschek, P.; Fankhauser, C. Light-regulated plant growth and development. Curr. Top. Dev. Biol. 2010, 91, 29-66.

89. Leivar, P.; Monte, E.; Oka, Y.; Liu, T.; Carle, C.; Castillon, A.; Huq, E.; Quail, P.H. Multiple phytochrome-interacting bHLH transcription factors repress premature seedling photomorphogenesis in darkness. Curr. Biol. 2008, 18, 1815-1823. [CrossRef]

90. Shi, H.; Lyu, M.; Luo, Y.; Liu, S.; Li, Y.; He, H.; Wei, N.; Deng, X.W.; Zhong, S. Genome-wide regulation of light-controlled seedling morphogenesis by three families of transcription factors. Proc. Natl. Acad. Sci. USA 2018, 115, 6482-6487. [CrossRef]

91. Mathews, S. Phytochrome-mediated development in land plants: Red light sensing evolves to meet the challenges of changing light environments. Mol. Ecol. 2006, 15, 3483-3503. [CrossRef]

92. Zhou, Y.; Zhang, D.; An, J.; Yin, H.; Fang, S.; Chu, J.; Zhao, Y.; Li, J. TCP transcription factors regulate shade avoidance via directly mediating the expression of both PHYTOCHROME INTERACTING FACTORs and auxin biosynthetic genes. Plant Physiol. 2018, 176, 1850-1861. [CrossRef]

93. Quint, M.; Delker, C.; Franklin, K.A.; Wigge, P.A.; Halliday, K.J.; van Zanten, M. Molecular and genetic control of plant thermomorphogenesis. Nat. Plants 2016, 2, 15190. [CrossRef]

94. Wigge, P.A. Ambient temperature signalling in plants. Curr. Opin. Plant Biol. 2013, 16, 661-666. [CrossRef] [PubMed]

95. Zhou, Y.; Xun, Q.; Zhang, D.; Lv, M.; Ou, Y.; Li, J. TCP transcription factors associate with PHYTOCHROME INTERACTING FACTOR 4 and CRYPTOCHROME 1 to regulate thermomorphogenesis in Arabidopsis thaliana. Iscience 2019, 15, 600-610. [CrossRef] [PubMed]

96. Franklin, K.A.; Lee, S.H.; Patel, D.; Kumar, S.V.; Spartz, A.K.; Gu, C.; Ye, S.Q.; Yu, P.; Breen, G.; Cohen, J.D.; et al. PHYTOCHROME-INTERACTING FACTOR 4 (PIF4) regulates auxin biosynthesis at high temperature. Proc. Natl. Acad. Sci. USA 2011, 108, 20231-20235. [CrossRef] [PubMed]

97. Sun, J.Q.; Qi, L.L.; Li, Y.N.; Chu, J.F.; Li, C.Y. PIF4-mediated activation of YUCCA8 expression integrates temperature into the auxin pathway in regulating Arabidopsis hypocotyl growth. PLoS Genet. 2012, 8 , e1002594. [CrossRef] [PubMed]

98. Hogenhout, S.A.; Oshima, K.; Ammar, E.D.; Kakizawa, S.; Kingdom, H.N.; Namba, S. Phytoplasmas: Bacteria that manipulate plants and insects. Mol. Plant Pathol. 2008, 9, 403-423. [CrossRef]

99. Reichel, M.; Millar, A.A. Specificity of plant microRNA target MIMICs: Cross-targeting of miR159 and miR319. J. Plant Physiol. 2015, 180, 45-48. [CrossRef]

100. Llave, C.; Xie, Z.X.; Kasschau, K.D.; Carrington, J.C. Cleavage of Scarecrow-like mRNA targets directed by a class of Arabidopsis miRNA. Science 2002, 297, 2053-2056. [CrossRef]

101. Palatnik, J.F.; Wollmann, H.; Schommer, C.; Schwab, R.; Boisbouvier, J.; Rodriguez, R.; Warthmann, N.; Allen, E.; Dezulian, T.; Huson, D.; et al. Sequence and expression differences underlie functional specialization of Arabidopsis microRNAs miR159 and miR319. Dev. Cell 2007, 13, 115-125. [CrossRef]

102. Sun, X.D.; Wang, C.D.; Xiang, N.; Li, X.; Yang, S.H.; Du, J.C.; Yang, Y.P.; Yang, Y.Q. Activation of secondary cell wall biosynthesis by miR319-targeted TCP4 transcription factor. Plant Biotechnol. J. 2017, 15, 1284-1294. [CrossRef]

103. Vadde, B.V.L.; Challa, K.R.; Nath, U. The TCP4 transcription factor regulates trichome cell differentiation by directly activating GLABROUS INFLORESCENCE STEMS in Arabidopsis thaliana. Plant J. 2018, 93, 259-269. [CrossRef]

104. Wang, H.; Mao, Y.; Yang, J.; He, Y. TCP24 modulates secondary cell wall thickening and anther endothecium development. Front. Plant Sci. 2015, 6, 436. [CrossRef] [PubMed]

105. Li, Y.; Li, C.Q.; Ding, G.H.; Jin, Y.X. Evolution of MIR159/319 microRNA genes and their post-transcriptional regulatory link to siRNA pathways. Bmc Evol. Biol. 2011, 11, 122. [CrossRef]

106. Tsuzuki, M.; Nishihama, R.; Ishizaki, K.; Kurihara, Y.; Matsui, M.; Bowman, J.L.; Kohchi, T.; Hamada, T.; Watanabe, Y. Profiling and characterization of small rnas in the liverwort, Marchantia polymorpha, belonging to the first diverged land plants. Plant Cell Physiol. 2016, 57, 359-372. [CrossRef] [PubMed]

107. Flores-Sandoval, E.; Dierschke, T.; Fisher, T.J.; Bowman, J.L. Efficient and inducible use of artificial microRNAs in Marchantia polymorpha. Plant Cell Physiol. 2016, 57, 281-290. [CrossRef]

108. Axtell, M.J.; Snyder, J.A.; Bartel, D.P. Common functions for diverse small RNAs of land plants. Plant Cell 2007, 19, 1750-1769. [CrossRef] [PubMed] 
109. Talmor-Neiman, M.; Stav, R.; Frank, W.; Voss, B.; Arazi, T. Novel micro-RNAs and intermediates of micro-RNA biogenesis from moss. Plant J. 2006, 47, 25-37. [CrossRef] [PubMed]

110. Warthmann, N.; Das, S.; Lanz, C.; Weigel, D. Comparative analysis of the MIR319a microRNA locus in Arabidopsis and related Brassicaceae. Mol. Biol. Evol. 2008, 25, 892-902. [CrossRef] [PubMed]

111. Clapier, C.R.; Cairns, B.R. The biology of chromatin remodeling complexes. Annu. Rev. Biochem. 2009, 78, 273-304. [CrossRef]

112. Ho, L.; Crabtree, G.R. Chromatin remodelling during development. Nature 2010, 463, 474-484. [CrossRef]

113. Tang, X.R.; Hou, A.F.; Babu, M.; Nguyen, V.; Hurtado, L.; Lu, Q.; Reyes, J.C.; Wang, A.M.; Keller, W.A.; Harada, J.J.; et al. The Arabidopsis BRAHMA chromatin-remodeling ATPase is involved in repression of seed maturation genes in leaves. Plant Physiol. 2008, 147, 1143-1157. [CrossRef] [PubMed]

114. Hurtado, L.; Farrona, S.; Reyes, J.C. The putative SWI/SNF complex subunit BRAHMA activates flower homeotic genes in Arabidopsis thaliana. Plant Mol. Biol. 2006, 62, 291-304. [CrossRef] [PubMed]

115. Efroni, I.; Han, S.-K.; Kim, H.J.; Wu, M.-F.; Steiner, E.; Birnbaum, K.D.; Hong, J.C.; Eshed, Y.; Wagner, D. Regulation of leaf maturation by chromatin-mediated modulation of cytokinin responses. Dev. Cell 2013, 24, 438-445. [CrossRef] [PubMed]

116. Tao, Q.; Guo, D.; Wei, B.; Zhang, F.; Pang, C.; Jiang, H.; Zhang, J.; Wei, T.; Gu, H.; Qu, L.-J.; et al. The TIE1 transcriptional repressor links TCP transcription factors with TOPLESS/TOPLESS-RELATED corepressors and modulates leaf development in Arabidopsis. Plant Cell 2013, 25, 421-437. [CrossRef] [PubMed]

117. Diao, Y.; Zhan, J.; Zhao, Y.; Liu, L.; Liu, P.; Wei, X.; Ding, Y.; Sajjad, M.; Hu, W.; Wang, P.; et al. GhTIE1 regulates branching through modulating the transcriptional activity of TCPs in cotton and Arabidopsis. Front. Plant Sci. 2019, 10, 1348. [CrossRef]

118. Wei, B.; Zhang, J.; Pang, C.; Yu, H.; Guo, D.; Jiang, H.; Ding, M.; Chen, Z.; Tao, Q.; Gu, H.; et al. The molecular mechanism of SPOROCYTELESS/NOZZLE in controlling Arabidopsis ovule development. Cell Res. 2015, 25, 121-134. [CrossRef]

119. Guilfoyle, T.; Hagen, G.; Ulmasov, T.; Murfett, J. How does auxin turn on genes? Plant Physiol. 1998, 118, 341-347. [CrossRef]

120. Kepinski, S.; Leyser, O. The Arabidopsis F-box protein TIR1 is an auxin receptor. Nature 2005, 435, $446-451$. [CrossRef]

121. Chapman, E.J.; Estelle, M. Mechanism of auxin-regulated gene expression in plants. Annu. Rev. Genet. 2009, 43, 265-285. [CrossRef]

122. Zhang, J.; Wei, B.; Yuan, R.; Wang, J.; Ding, M.; Chen, Z.; Yu, H.; Qin, G. The Arabidopsis RING-Type E3 ligase TEAR1 controls leaf development by targeting the TIE1 transcriptional repressor for degradation. Plant Cell 2017, 29, 243-259. [CrossRef]

123. Reinhardt, B.; Hanggi, E.; Muller, S.; Bauch, M.; Wyrzykowska, J.; Kerstetter, R.; Poethig, S.; Fleming, A.J. Restoration of DWF4 expression to the leaf margin of a dwf4 mutant is sufficient to restore leaf shape but not size: The role of the margin in leaf development. Plant J. 2007, 52, 1094-1104. [CrossRef] [PubMed]

124. Li, S.; Zachgo, S. TCP3 interacts with R2R3-MYB proteins, promotes flavonoid biosynthesis and negatively regulates the auxin response in Arabidopsis thaliana. Plant J. 2013, 76, 901-913. [CrossRef] [PubMed]

125. Rameau, C.; Bertheloot, J.; Leduc, N.; Andrieu, B.; Foucher, F.; Sakr, S. Multiple pathways regulate shoot branching. Front. Plant Sci. 2014, 5, 741. [CrossRef] [PubMed]

126. Braun, N.; de Saint Germain, A.; Pillot, J.-P.; Boutet-Mercey, S.; Dalmais, M.; Antoniadi, I.; Li, X.; Maia-Grondard, A.; Le Signor, C.; Bouteiller, N.; et al. The Pea TCP transcription factor PsBRC1 acts downstream of strigolactones to control shoot branching. Plant Physiol. 2012, 158, 225-238. [CrossRef] [PubMed]

127. Qin, G.J.; Gu, H.Y.; Zhao, Y.D.; Ma, Z.Q.; Shi, G.L.; Yang, Y.; Pichersky, E.; Chen, H.D.; Liu, M.H.; Chen, Z.L.; et al. An indole-3-acetic acid carboxyl methyltransferase regulates Arabidopsis leaf development. Plant Cell 2005, 17, 2693-2704. [CrossRef]

(C) 2020 by the authors. Licensee MDPI, Basel, Switzerland. This article is an open access article distributed under the terms and conditions of the Creative Commons Attribution (CC BY) license (http://creativecommons.org/licenses/by/4.0/). 